\title{
Tinjauan Yuridis Perkara Pembatalan Hibah (Studi Kasus Putusan Nomor 467 K/Ag2017)
}

\author{
Robiah Awaliyah ${ }^{1}$ dan Nadjematul Faizah ${ }^{2}$
}

\section{Abstrak}

Studi ini bertujuan untuk mendeskripsikan pertimbangan hukum hakim dalam memutus perkara pembatalan hibah atas harta bersama yang diberikan oleh orang tua kepada anak sebagai syarat terjadinya perceraian dalam putusan Nomor 467 K/Ag2017. Penelitian ini menggunakan metode pendekatan perundang-undangan (statue approach) dan pendekatan kasus (case approach) dengan menggunakan penelitian kepustakaan (library research). Sumber data Primer dalam penelitian ini adalah berkas putusan Nomor 467 K/Ag2017. Hasil penelitian ini menunjukkan bahwa perbedaan dasar pertimbangan dalam memutus perkara pembatalan hibah atas harta bersama. Hakim Pengadilan Agama Surabaya berpendapat bahwa pemberian hibah yang dilakukan Penggugat terhadap Para Tergugat ialah tidak berdasarkan hukum. Sehingga gugatan Penggugat terkait pembatalan hibah tidak dikabulkan oleh Hakim Pengadilan Agama Surabaya. Hakim Pengadilan Agama Surabaya merujuk pada Pasal 1678 KUH Perdata yang menyatakan bahwa penghibahan antara suami istri selama pekawinan mereka masih berlangsung, dilarang. Sedangkan Hakim Pengadilan Tinggi Agama Surabaya dan Mahkamah Agung berpendapat bahwa pemberian hibah yang dilakukan Penggugat terhadap Para Tergugat ialah berdasarkan hukum. Karena Penggugat dan Tergugat telah setuju melakukan penghibahan atas harta bersama yang diberikan kepada anak-anaknya kala itu. Namun gugatan terkait pembatalan hibah dari tingkat pertama hingga kasasi tetap tidak dikabulkan oleh Hakim. Jika dilihat pada Pasal 212 KHI yang menyatakan bahwa hibah tidak dapat ditarik kembali kecuali hibah orang tua kepada anaknya, maka gugatan terkait pembatalan hibah tersebut dapat dipertimbangkan untuk dikabulkan sebagian.

Kata Kunci: Pembatalan Hibah, Harta Bersama, Putusan Pengadilan

\section{Abstract}

This study aims to describe the legal considerations of judges in deciding cases of cancellation of grants for joint assets given by parents to children as a condition for divorce in decision Number $467 \mathrm{~K} / \mathrm{Ag} 2017$. This study uses a statutory approach method (statue approach) and a case approach using library research (library research). Primary data source in this study is the decision file Number $467 \mathrm{~K} / \mathrm{Ag} 2017$. The results of this study indicate that there are differences in the basic considerations in deciding cases of cancellation of grants on joint assets. The Judge of the Surabaya Religious Court was of the

\footnotetext{
${ }^{1}$ Alumni Institut Ilmu Al-Qur'an (IIQ) Jakarta

${ }^{2}$ Dosen Institut Ilmu Al-Qur'an (IIQ) Jakarta

Tinjauan Yuridis Perkara Pembatalan Hibah 
opinion that the grant giving by the Plaintiff to the Defendants was not based on law. So that the Plaintiff's claim regarding the cancellation of the grant was not granted by the Surabaya Religious Court Judge. The Surabaya Religious Court judges referred to Article 1678 of the Civil Code which states that granting between husband and wife while their marriage is still ongoing is prohibited. Meanwhile, the Judges at the High Religious Courts in Surabaya and the Supreme Court are of the opinion that the grants made by the Plaintiff to the Defendants were based on law. Because the Plaintiff and Defendant have agreed to grant the joint assets given to their children at that time. However, the Judge did not grant the lawsuit regarding the cancellation of the grant from the first stage to the cassation. If seen in Article $212 \mathrm{KHI}$ which states that a grant cannot be withdrawn except for a parent's grant to his child, then a claim related to the cancellation of the grant can be considered for partial granting.

Keywords: Grant Cancellation, Collective Property, Court Decision

\section{A. PENDAHULUAN}

Menurut Undang-Undang No. 1 Tahun 1974 tentang Perkawinan pasal 1 menyatakan bahwa: "Perkawinan adalah ikatan lahir batin antara seorang pria dengan seorang wanita sebagai suami istri dengan tujuan membentuk keluarga (rumah tangga) yang bahagia dan kekal berdasarkan Ketuhanan Yang Maha Esa" (Undang-Undang No. 1 Tahun 1974 Tentang Perkawinan Pasal 1). Dalam Inpres No 1 Tahun 1991 Kompilasi Hukum Islam pasal 2 menyatakan bahwa:

Perkawinan adalah pernikahan, yaitu akad yang sangat kuat atau mitsâqan ghalîdzan untuk mentaati perintah Allah dan melaksanakannya merupakan ibadah" (Instruksi Presiden Republik Indonesia Nomor 1 Tahun 1991 Tentang Kompilasi Hukum Islam).

Dalam Undang-Undang Perkawinan No 1 Tahun 1974 telah diatur mengenai hak dan kewajiban suami istri untuk menunjangnya kelurga yang sakînah, mawaddah, wa rahmah. Hak dan kewajiban suami istri dalam Undang-Undang No. 1 Tahun 1974 terdapat dalam Bab VI pasal 30-34. Menurut undang-undang ini, kedudukan hak dan kewajiban suami istri adalah setara. Jika suami istri melalaikan kewajibannya masing-masing, maka dapat mengajukan gugatan di muka pengadilan.

Kehidupan berkeluarga tidak terlepas dari masalah-masalah yang dihadapi, baik masalah dari dalam keluarga maupun dari luar keluarga. Pada masa sekarang ini banyak perkawinan yang harus berakhir dengan perceraian. Putusnya perkawinan atau perceraian merupakan alternatif terakhir yang ditempuh apabila kehidupan 
berumah tangga tidak dapat dipertahakan lagi. Selanjutnya apabila terjadi perceraian tentu akan membawa akibat hukum sebagai konsekuensi dari perceraian tersebut, salah satunya terhadap harta bersama yang diperoleh selama perkawinan.

Dalam Undang-Undang No 1 tahun 1974 pasal 35 harta bersama ialah harta benda yang diperoleh selama perkawinan. Masing-masing suami dan istri memiliki hak dan kewajiban yang sama atas harta tersebut dan segala tindakan hukum atas harta benda tersebut harus mendapat persetujuan dari kedua belah pihak, termasuk keinginan suami maupun istri untuk menghibahkan harta bersama tersebut kepada anak-anaknya. Permasalahan yang terjadi tentang hibah yang bersumber dari harta bersama adalah apabila terdapat pencabutan hibah atas kehendak salah satu pihak setelah terjadinya perceraian.

Merujuk dari paparan diatas terkait harta bersama dan hibah penulis tertarik mengenai kasus putusan Pengadilan Agama Surabaya No. 467/K/Ag 2017. Dalam kasus putusan ini H. Rasmidjan (suami) selaku penggugat mengajukan gugatan pembatalan hibah terhadap istri dan kelima anaknya, yang kala itu akadnya diwakilkan oleh sang ibu (istri penggugat). Diketahui bahwa antara suami dan istri telah membuat pernyataan bersama dibawah tangan yang dibuat pada tanggal 12 Februari 1981 mengenai penghibahan seluruh harta bersama kepada anak-anak sebagai syarat istri agar mau dicerai oleh suami.

Namun pada tahun 2016 suami mengajukan gugatan untuk melakukan pembatalan hibah kepada mantan istri dan anaknya tersebut, dan membawa perkara ini ke Pengadilan Agama Surabaya untuk mendapatkan haknya. Namun putusan pertimbangan hakim menyatakan permohonan gugatan pembatalan hibah tersebut di tolak, dikarenakan ketika penggugat memberi harta hibah tersebut kepada tergugat yaitu kelima anak yang diwakilkan oleh ibu atas dasar rela sama rela.

Dari latar belakang di atas maka dari sini penulis tertarik untuk menganalisis dan melakukan penelitian mengenai kedudukan harta bersama yang dihibahkan kepada anak sebagai syarat persetujuan perceraian, serta mengetahui kesesuaian peraturan yang ada dengan putusan hakim dalam melakukan pembatalan gugatan yang diajukan oleh Penggugat. 


\section{B. TELAAH PUSTAKA}

\section{Pengertian Hibah}

Dalam Kamus Besar Bahasa Indonesia hibah berarti pemberian dengan sukarela dengan mengalihkan hak atas sesuatu kepada orang lain (KBBI, 2002:398). 15 Menurut definisi syara', hibah adalah akad pemberian kepemilikan kepada orang lain tanpa adanya imbalan, yang dilakukan secara sukarela ketika pemberi masih hidup (Wahbah AzZuhaili, 2011: 523). Sementara itu menurut istilah, hibah adalah akad yang berisi pemberian sesuatu oleh seseorang atas hartanya kepada orang lain ketika dia masih hidup, tanpa penukar (Sayyid Sabiq, 2009:449-450).

Adapun pendapat empat imam mazhab mengenai definisi hibah adalah sebagai berikut (Abdurrahman Al-Jaziry, Fiqh Empat Mazhab, t.t: 425):

1. Menurut Mazhab Hanafi, hibah adalah memberikan hak memiliki suatu benda dengan tanpa adanya syarat harus mendapatkan imbalan ganti, pemberian tersebut dilakukan pada saat si pemberi hibah masih hidup.

2. Menurut Mazhab Maliki, hibah sama dengan hadiah. Apabila niat si pemberi tersebut ialah semata-mata untuk mendapat ridha Allah dan mengharapkan pahala-Nya, maka menurut mazhab Maliki ini dinamakan sedekah.

3. Menurut Mazhab Hambali, hibah diartikan sebagai pemberian kepemilikan pada suatu harta yang diketahui atau tidak diketahui, ada, yang dapat diserahkan, hukumnya tidak wajib dan dilakukan ketika masih hidup tanpa adanya ganti dengan lafal yang menurut kebiasaan adalah hibah (Wahbah Az-Zuhaili, 2011: 523).

4. Menurut Mazhab Syafi'I, hibah mempunyai dua macam arti, yaitu:

a. Umum: Mencakup hadiah, hibah dan shadaqah.

b. Khusus: Hanya tertentu pada hibah sendiri kemudian dinamakan hibah zatil arkan (pemberian yang mempunyai rukun-rukun).

Dalam mazhab Syafi'I terdapat perbedaan hibah dalam arti khusus dengan sedekah dan hadiah. Apabila pemberian itu dimaksudkan atas kebaikan semata bukan karena dorongan cinta, niat untuk menghormati serta tidak pula demaksudkan untuk memperoleh 
ridha Allah dan mendapatkan pahala-Nya, maka pemberian tersebut dinamakan hibah.

Sedangkan jika pemberian sesuatu tersebut diberikan dengan niat mendapat ridha Allah dan memperoleh pahala-Nya, maka hal itu dinamakan sedekah. Kemudian, apabila pemberian tersebut dimaksudkan untuk menghormati atau memuliakan kepada orang yang diberinya, maka hal itu dinamakan hadiah. Perbedaan lain menurut mazhab Syafi'I adalah hibah memerlukan adanya ijab dan qabul, sedangkan hadiah dan shadaqah tidak memerlukan adanya ijab dan qabul (Ramulyo, 1994: 146).

Dalam Kitab Undang-Undang Hukum Perdata Pasal 1666 menyatakan bahwa: "Hibah adalah suatu perjanjian dengan mana si penghibah, di waktu hidupnya, dengan Cuma-Cuma dan dengan tidak dapat ditarik kembali, menyerahkan sesuatu benda guna keperluan si penerima hibah yang menerima penyerahan itu" (Subekti, 1999:436). Pembahasan hibah juga terdapat di Kompilasi Hukum Islam, yang merupakan rujukan hukum umat muslim dalam hal keperdataan di Indonesia. Menurut Kompilasi Hukum Islam pasal 171 huruf g, hibah adalah pemberian suatu benda secara sukarela dan tanpa imbalan dari seseorang kepada orang lain yang masih hidup untuk dimiliki (Instruksi Presiden Republik Indonesia No 1 Tahun 1991 tentang Kompilasi Hukum Islam Pasal 171 Huruf g).

Dari definisi-definisi diatas dapat ditarik kesimpulan bahwa hibah adalah suatu pemberian harta kekayaan secara sukarela dari seseorang, baik berbentuk materi maupun benda yang diberikan atas dasar kebaikan semata dan tanpa syarat di waktu ia masih hidup dengan tanpa adanya imbalan.

\section{Dasar Hukum Hibah}

\section{Al-Qur'an}

Di dalam Al-Qur'an untuk menentukan dasar hukum melakukan hibah secara langsung memang tidak ditemukan. Dalam Al-Qur'an, penggunaan kata hibah digunakan dalam konteks pemberian anugrah Allah kepada utusan-utusan-Nya, doa-doa yang dipanjatkan hambahamba-Nya terutama para Nabi, dan menjelaskan mengenai sifat Allah yang Maha Memberi Karunia.

Dimana hal tersebut dapat digunakan sebagai petunjuk dan anjuran secara umum agar seseorang memberikan sebagian rezekinya kepada orang lain (Rofiq, 2013: 275). 
Islam menganjurkan agar umatnya saling memberi, saling tolongmenolong, dan saling kasih antar sesamanya. Salah satu bentuk tolong menolong dalam harta ialah memberikan harta berupa hibah (Wahbah Az-Zuhaili, 2011: 523). 24 Seperti yang dijelaskan dalam firman Allah dalamSurah Al-Maidah ayat 2 yaitu:
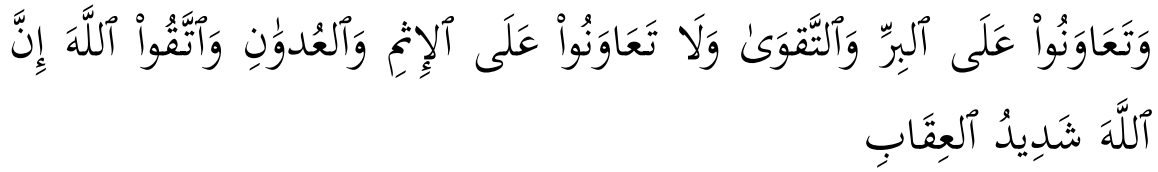

Artinya: "Dan tolong-menolonglah kamu dalam (mengerjakan) kebajikan dan takwa, dan jangan tolong-menolong dalam berbuat dosa dan pelanggaran. Dan bertakwalah kamu kepada Allah, sesungguhnya Allah amat berat siksa-Nya"

\section{Hadist}

"Muhammad ibn Muammar berbicara kepada kami, Hamid ibn Hammad ibn Abi al-Khuwar memberi tahu kami, Ayadh ibn Shurayh berkata: Saya mendengar Anas Ibn Malik $\square$ berkata: bahwa Rasulullah SAW bersabda: "wahai orang anshar senantiasa memberi hadiahlah kalian, maka itu akan menghilangkan kedengkian" (HR.Bazzar). (Abu Bakar Ahmad bin Amru bin Abdul Khaliq bin Khollad bin Ubaidillah Al-Ataki (Bazzar), Musnad al-Bazar (al-Bahr al-Zakhkhar), (Madinah: Perpustakaan Ilmu Pengetahuan dan Pemerintahan), Juz18 Nomor 7529).

Baik ayat maupun hadis yang telah dipaparkan di atas menunjukkan anjuran untuk saling memberi, saling tolong-menolong, dan saling kasih antar sesamanya. Terkait itu, islam sangat menganjurkan seseorang yang mempunyai kelebihan harta untuk memberikan hartanya kepada yang memerlukan, salah satunya dengan memberikan hibah.

\section{Rukun dan Syarat Hibah}

Rukun merupakan unsur persyaratan yang harus dipenuhi dalam sebuah ibadah, tak terkecuali hibah. Apabila rukun hibah tersebut belum terpenuhi maka belum dapat dikatakan sebagai hibah. Rukun hibah menurut jumhur ulama ada empat, yaitu (Rofiq, 2013: 375):

a. Orang yang menghibahkan (al-wahib)

Orang yang menghibahkan ialah orang yang dalam kondisi sehat dan sebagai pemilik yang mempunyai hak penuh atas benda yang dihibahkannya.

b. Orang yang menerima hibah (al-mauhub lah) 
Hibah dapat diberikan kepada siapa saja yang dikehendaki oleh si pemberi hibah (al-wahib).

c. Benda yang dihibahkan (al-mauhub)

Benda yang dihibahkan ialah benda yang menjadi hak milik baik berupa benda bergerak maupun benda tidak bergerak.

d. Sighat

Sighat adalah ijab dan qabul, yaitu berupa ucapan atau perkataan dari orang yang bisa berbicara dan termasuk ijab yang jelas jika dia mengatakan: "saya hibahkan kepada kamu, saya berikan kepadamu, saya jadikan milikmu tanpa bayaran" dan lain-lain, dan termasuk qabul yang jelas seperti ucapan "saya terima, saya ridha", yang semua ini diucapkan dengan niat hibah (Ajib, 2019: 18).

Sedangkan yang termasuk syarat dalam pelaksaan hibah ialah (Wahbah Az-Zuhaili, 2011: 530-532):

a. Syarat pemberi hibah

Syarat pemberi hibah ialah orang yang memiliki kewenangan untuk memberi hibah, yaitu berakal, baligh, dan menjaga harta. Kemudian syarat selanjutnya ialah tidak dalam keadaan terpaksa. Jika harta benda tersebut di hibahkan karena adanya paksaan, maka sudah pasti perbuatan itu tidak sah.

b. Syarat orang yang menerima hibah

Syarat orang yang menerima hibah ialah benar-benar ada ketika hibah diberikan. Jika dia sama sekali tidak ada atau baru dianggap ada, misalnya dia masih berbentuk janin, maka hibah tersebut tidak sah. Jika orang yang diberi hibah adalah benarbenar ada ketika hibah diberikan, tapi masih kecil atau gila, maka hibah diterima oleh walinya, orang yang diwasiati untuk mengurusinya atau orang yang merawatnya, meskipun dia adalah orang asing.

c. Syarat barang yang dihibahkan

Syarat barang yang dihibahkan ialah benda tersebut ada ketika dihibahkan. Benda tersebut benda yang bernilai dan dapat dimiliki. Maksudnya dapat dimiliki ialah dapat di pindah tangankan. Kemudian benda tersebut ialah milik pemberi, karena tidak sah menghibahkan harta milik orang lain tanpa seizin pemiliknya. 
d. Syarat shigat, ijab qabul harus didasarkan pada kesepakatan bebas dari para pihak, tanpa adanya unsur paksaan, kekhilafan, atau penipuan. Pernyataan ijab qabul dapat dilaksanakan baik lisan maupun tertulis. (Mardani, 2014:130).

\section{Kadar atau kapasitas hibah}

Mengenai kadar atau kapasitas harta yang boleh dihibahkan tidak dijelaskan secara detail di dalam nash. Jumhur ulama mengatakan bahwa seseorang boleh menghibahkan semua harta yang dimilikinya kepada orang lain. Sementara itu, Muhammad Hasan dan beberapa ulama dari mazhab Hanafi berpendapat, bahwa tidak sah menghibahkan semua harta, meskipun untuk keperluan kebaikan.

Mereka menganggap, orang yang berbuat demikian itu sebagai orang yang dungu (Anshori, 2011:81). Penulis ar-Raudhah anNadiyyah telah mengkaji permasalahan ini dan berkata: "Barang siapa yang memiliki kesabaran menghadapi kemiskinan, maka tidak masalah baginya untuk menyedekahkan sebagian besar hartanya atau semuanya. Dan barang siapa yang masih hendak meminta-minta kepada manusia jika membutuhkan sesuatu, maka tidak halal baginya untuk menyedekahkan semua hartanya atau sebagian besarnya. Inilah perbedaan antara hadis-hadis yang menunjukkan tidak dibolehkannya menyedekahkan lebih dari sepertiga harta dan dalil-dalil yang menunjukkan dibolehkannya menyedekahkan lebih dari sepertiga hartanya" (Sayyid Sabiq, 2009:449-450).

Dari uraian diatas dapat ditarik kesimpulan bahwa sebaiknya seseorang dalam menghibahkan hartanya tidak lebih dari sepertiga harta, seperti yang tercantum juga dalam pasal 210 ayat 1 Kompilasi Hukum Islam yang menyatakan bahwa harta yang dapat dihibahkan sebanyak-banyaknya $1 / 3$ dari keseluruhan harta bendanya kepada orang lain atau lembaga, karena dikhawatirkan akan menimbulkan kerugian dan penyesalan di kemudian hari, walaupun pemberian hibah itu dilakukan oleh orang tua terhadap anaknya (Instruksi Presiden Republik Indonesia Nomor 1 Tahun 1991 Tentang Kompilasi Hukum Islam).

\section{Macam-macam hibah}

Hibah adalah suatu pemberian harta kekayaan secara sukarela dari seseorang, baik berbentuk materi maupun benda yang diberikan atas dasar kebaikan semata dan tanpa syarat di waktu ia masih hidup 
dengan tanpa adanya imbalan. Adapun macam-macam hibah diantaranya ialah:

\section{a. Hibah manfaat}

Hibah manfaat ialah memberikan harta kepada orang lain agar barang atau harta tersebut dapat dimanfaatkan, namun kedudukan harta atau barang tersebut tetao menjadi milik pemberi hibah. Dengan kata lain, hibah manfaat merupakan hibah yang penerimanya hanya memiliki hak guna atau hak pakai saja.

Apabila penerima hibah meninggal dunia terlebih dahulu, maka harta atau barang yang dihibahkan tersebut dikembalikan kepada pemberi hibah. Selanjutnya Imam Malik mengemukakan bahwa apabila dalam akad pemberian hibah itu disebutkan jika penerima hibah meninggal dunia dan barang yang dihibahkan tersebut diserahkan kepada keturunannya, maka hal ini dibenarkan, dan jika keturunannya sudah tidak ada lagi maka barang yang dihibahkan itu dikembalikan kepada pemberi hibah atau ahli warisnya (Manan, 2008: 143).

\section{b. Hibah barang}

Hibah barang ialah memberikan harta atau barang kepada pihak lain yang mencakup nilai materi atau manfaat dari harta atau barang tersebut, yang pemberiannya itu tanpa ada harapan apapun.

\section{Penarikan Kembali Hibah}

Larangan mengambil kembali hibah yang telah diberikan telah dijelaskan pada hadist di bawah ini:

"Telah menceritakan kepada kami Muslim bin Ibrahim, telah menceritakan kepada kami Wuhaib, telah menceritakan kepada kami Ibnu Thawus dari ayahnya, dari Ibnu Abbas r.a bahwa Nabi SAW bersabda: "Orang yang menarik kembali pemberiannya bagaikan anjing yang muntah kemudian menjilat kembali muntahannya". (HR.Bukhari). (Dar Touq Al-Najah, Juz 9 Nomor 2589).

Dari hadis yang telah disebutkan di atas dapat diambil kesimpulan bahwa seseorang yang telah memberikan suatu pemberian kepada orang lain tidak diperbolehkan mengambil kembali pemberiannya. Orang yang menarik kembali pemberiannya itu diibaratkan seperti anjing yang memakan kembali muntahannya.

Menurut Hukum Islam, pada dasarnya semua perjanjian yang dilakukan atas dasar suka rela, seperti melakukan hibah, dapat dicabut kembali, meskipun tidak semua pemberian hibah dapat dicabut 
kembali oleh pemberi hibah. Dalam beberapa hal penarikan kembali hibah memerlukan persetujuan pihak penerima hibah atau dasar persetujuan pengadilan (Suparman, 2007:81). Jumhur ulama mengharamkan penarikan kembali hibah, mesipun hibah tersebut terjadi antara saudara atau suami istri. Kecuali seorang ayah yang berhibah kepada anaknya, maka hibahnya boleh diambil kembali (Sayyid Sabiq, 2009:61). Sebagaimana hadis Rasulullah SAW:

"Telah menceritakan kepada kami Yazid, memberitahukan kepada kami Husain Ibnu Dzakwan, dari Umar bin Syu'aib, dari Thawus, dari Ibnu Umar dan Ibnu Abbas bahwa Nabi SAW bersabda: "Tidak halal bagi seorang muslim memberikan suatu pemberian kemudian menariknya kembali, kecuali seorang ayah yang menarik kembali apa yang diberikan kepada anaknya". Perumpaan orang yang memberi kemudian menariknya kembali seperti anjing yang makan sampai kenyang, kemudian muntah, lalu memakan muntahannya kembali. (HR. Ahmad bin Hambal). (Musnad Imam Ahmad Bin Hambal, Nomor 2119).

Dari kedua hadist diatas dapat ditarik kesimpulan bahwa, hibah yang ditarik kembali ialah dilarang. Orang yang menarik kembali hibahnya diibaratkan seperti anjing yang memakan kembali muntahannya. Namun terdapat pengecualian yaitu hibah orang tua terhadap anaknya yang dapat ditarik kembali. Hal itu dibolehkan mengingat jasa orang tua kita telah menyayangi kita. Jadi apabila orang tua menarik kembali hartanya yang telah di hibahkan kepada anaknya, maka penarikan itu dapat dibenarkan.

\section{Penarikan Hibah Menurut Kompilasi Hukum Islam}

Kompilasi Hukum Islam merupakan rujukan hukum umat muslim dalam hal keperdataan di Indonesia. Ketentuan mengenai hibah terdapat pada Buku II Bab VI Kompilasi Hukum Islam, 38 yaitu Pasal 210 sampai dengan pasal 214. Dalam pasal 210 ayat 1 disebutkan bahwa orang yang menghibahkan haruslah berumur sekurang- kurangnya 21 tahun, berakal sehat, tanpa adanya paksaan, dan harta yang dapat dihibahkan sebanyak-banyaknya $1 / 3$ dari keseluruhan harta bendanya kepada orang lain atau lembaga di hadapan dua orang saksi dan harta yang dihibahkan tersebut merupakan hak dari penghibah (Instruksi Presiden Republik Indonesia Nomor 1 Tahun 1991 Tentang Kompilasi Hukum Islam). 
Jika yang dihibahkan melebihi $1 / 3$ dari harta si penghibah, maka hibahnya dapat dibatalkan karena tidak memenuhi syarat penghibahan. Selanjutnya dalam pasal 210 ayat (2) disebutkan bahwa "Harta benda yang dihibahkan harus merupakan hak dari penghibah". Dalam pasal ini yang dimaksud ialah pemberi hibah haruslah pemilik sah dari barang yang dihibahkan.

Dalam pasal 211 dijelaskan bahwa hibah yang diberikan orang tua kepada anaknya dapat diperhitungkan sebagai warisan. Hibah dapat diberikan kepada siapa saja tanpa memandang ras dan suku. Penjelasan mengenai Pasal 211 KHI, yang dikutip dari uraian Drs. Dede Ibin, S.H. (Wkl. Ketua PA Rangkasbitung) dalam tulisannya yang berjudul Hibah, Fungsi dan korelasinya dengan kewarisan ialah “pengertian 'dapat' yang terdapat dalam pasal tersebut bukan berarti keharusan, tetapi merupakam salah satu alternatif yang dapat ditempuh untuk menyelesaikan sengketa kewarisan.

Jika para ahi waris tidak mempersoalkan hibah yang sudah diberikan, maka harta warisan yang belum dihibahkan dapat dibagikan kepada ahli waris sesuai porsinya masing-masing. Tetapi apabila ada sebagian ahli waris yang mempermasalahkan atas hibah yang telah diberikan kepada ahli waris lainnya, maka hibah tersebut dapat di perhitingkan sebagai warisan. Dengan cara mengkalkulasikan hibah yang sudah diterima degan porsi warisan yang seharusnya diterima (Hukum Online, 2020)."

Dalam Pasal 212 menyatakan bahwa hibah tidak dapat ditarik kembali, kecuali hibah orang tua kepada anaknya. Hal ini mengingat jasa orang tua yang telah merawat dan menyayangi kita. Pada Pasal 213 diterangkan bahwa hibah yang dberikan pada saat pemberi hibah dalam keadaan sakit yang dekat dengan kematian, maka harus mendapat persetujuan dari para ahli warisnya.

Dalam Pasal 214 diatur mengenai teknis penghibahan yang dilakukan oleh Warga Negara Indonesia apabila berada di Negara Asing. Syarat yang harus dipenuhi bagi Warga Negara Indonesia tersebut ialah membuat surat hibah di hadapan Konsulat atau Kedutaan Republik Indonesia setempat, yang sepanjang isinya tidak bertentangan dengan ketentuan Kompilasi Hukum Islam (Zuhrotuniisa, 2017: 22). 


\section{Penarikan Hibah Menurut Kitab Undang-Undang Hukum Perdata} Hukum perdata merupakan hukum antar perorangan yang mengatur hak dan kewajiban perorangan antara satu dengan yang lain di dalam hubungan keluarga dan di dalam pergaulan masyarakat. Hukum perdata di Indonesia berasal dari Burgerlijk Wetboek Belanda, yang diberlakukan berdasarkan asas konkordansi (Hukum Online, 2020). Kitab Undang-Undang Hukum Perdata terdiri atas empat buku, yaitu:

1. Buku I, tentang Orang

2. Buku II, tentang Kebendaan

3. Buku III, tentang Perikatan

4. Buku IV, tentang Pembuktian dan Daluarsa

Dalam Kitab Undang-Undang Hukum Perdata pembahasan mengenai hibah terdapat pada Pasal 1666 sampai dengan Pasal 1693 (Subekti, Kitab Undang-undang Hukum Perdata). Sedangkan pembahasan mengenai penarikan hibah terdapat pada Bagian ke empat tentang penarikan kembali dan penghapusan hibah yang tercantum dalam pasal-pasal sebagai berikut:

\section{Pasal 1688}

Pada prinsipnya perjanjian hibah tidak dapat dicabut dan dibatalkan oleh pemberi hibah, namun ada tiga pengecualian yaitu:

1. Jika syarat-syarat penghibahan itu tidak dipenuhi oleh penerima hibah. Maksud dari ayat (1) ialah bahwa dalam melakukan hibah terdapat syarat-syarat yang harus dijalankan oleh si penerima hibah sesuai dengan apa yang telah diatur oleh undang-undang. Contohnya si penerima hibah belum/tidak ada pada saat penghibahan dilakukan (telah meninggal/belum dilahirkan) maka penghibahan tersebut dapat dibatalkan.

2. Jika orang yang diberi hibah bersaalah dengan melakukan atau ikut melakukan usaha pembunuhan atau suatu kejahatan lain atas diri penghibah. Maksud dari ayat (2) adalah suatu hibah dapat dibatalkan oleh pemberi hibah, apabila penerima hibah telah melakukan perbuatan- perbuatan yang dapat mengancam jiwa dan keselamatan pemberi hibah.

3. Jika pemberi hibah jatuh miskin, sedangkan penerima hibah menolak untuk memberi nafkah kepada pemberi hibah. Maksud dari ayat (3) ialah suatu hibah dapat dibatalkan oleh pemberi hibah apabila penerima hibah menolak untuk memberi bantuan nafkah 
kepada pemberi hibah, ketika pemberi hibah telah jatuh miskin atau menurun perekonomiannya. Walaupun sebenarnya pemberian bantuan berupa nafkah bukanlah hal yang wajib dalam suatu penghibahan, tetapi hal tersebut merupakan bentuk rasa kemanusiaan dan sebagai bentuk balas budi serta terima kasih terhadap pemberi hibah (Oping, 2017).

\section{Pasal 1689}

"Dalam hal yang pertama, barang yang dihibahkan setiap pada si penghibah atau ia dapat menuntutya kembali, bebas dari segala beban dan hipotik yang sekiranya telah diletakkan di atasnya oleh si penerima hibah, beserta hasil-hasil dan pendapatan-pendapatan yang ada pada si penerima hibah yang didapatnya sejak kelalaianya. Dalam hal yang demikian, si penghibah dapat, terhadap seorang pihak ke tiga yang menanggung benda tak bergerak yang telah dihibahkan, melaksanakan hak-hak yang sama sebagaimana dapat dilaksanakannya terhadap si penerima hibah sendiri."

\section{Pasal 1690}

"Dalam kedua hal yang terakhir disebutkan dalam pasal 1688, tidaklah dapat diganggu gugat pemindahtanganan barang yang dihibahkan atau hipotik-hipotik dan lain-lain beban kebendaan, yang sekiranya telah diletakkan di atas barang tersebut oleh si penerima hibah sebelum tuntutan untuk pembatalan hibah telah didaftarkan di samping pengumumam tersebut dalam pasal 616. Semua pemindahtanganan, hipotik atau lain-lain beban kebendaan yang dibuat terkemudian dari pada pendaftaran oleh si penerima hibah sebagaimana disebutkan di atas adalah batal, apabila tuntutan sebagai akibat penarikan kembali itu dikabukan."

Dalam pasal ini dijelaskan bahwa kedua benda yang telah dihibahkan dapat tetap pada si penerima hibah, apabila sebelumnya telah didaftarkan lebih dahilu. Dan apabila dikemudian hari penuntutan kembali dilakukan oleh si pemberi hibah dan dikabulkan maka semua perbuatan si penerima hibah dianggap batal.

\section{Pasal 1691}

"Si penerima hibah diwajibkan, dalam hal yang tersebut dalam pasal yang lalu, mengembalikan barang yang dihibahkan, dengan hasil-hasil dan pendapat-pendapatannya, terhitung mulai hari dimajukannya gugatan, atau jika benda telah dijualnya, mengembalikan harganya pada waktu dimasukkannya gugatan, pula disertai hasil-hasil dan pendapatan-pendapatan sejak saat itu. Selain dari pada itui diwajibkan memberikan ganti rugi kepada si penghibah, 
untuk hipoti-hipotik dan beban-beban lainnya yang telah diletakkan olehnya di atas benda-benda tak bergerak, juga sebelum gugatan dimasukkan."

\section{Pasal 1692}

"Tuntutan hukum tersebut dalam pasal yang lalu gugur dengan lewatnya waktu satu tahun, terhitung mulai terjadinya peristiwa yang menjadi alasan tuntutan itu, dan dapat diketahuinya hal itu oleh si penghibah. Tuntutan hukum tersebut tidak dapat dimajukan oleh si penghibah tehadap para ahli waris si penerima hibah, maupun oleh para ahli waris si pengibah terhadap si penerima hibah, terkecuali dalam hal yang terakhir, jika tuntutan itu dimajukan oleh si penghibah, ataupun jika orang ini telah meninggal di dalam waktu satu tahun setelah terjadinya peristiwa yang dituduhkan"

Dalam pasal 1692 dijelaskan bahwa tuntutan hukum terhadap si penerima hibah gugur dengan lewatnya waktu satu tahun terhitung mulai hari terjadinya peristiwa yang menjadi alasan tuntutan tersebut. Tuntutan hukum tidak dapat dilakukan oleh ahli waris si penghibah, kecuali apabila oleh si penghibah semula telah diajukan tuntutan ataupun telah meninggal dunia di dalam kurun satu tahun setelah terjadinya tuduhan tersebut (Zuhrotuniisa, 2017: 22).

\section{Pasal 1693}

"Ketentuan-ketentuan dalam bab ini tidak mengurangi berlakunya apa yang telah ditetapkan dalam bab ke tujuh Buku ke satu Kitab Undang-Undang (Subekti, Kitab Undang-undang Hukum Perdata: 440-441)".

\section{Hikmah Hibah}

Adapun hikmah dari dianjurkannya hibah diantaranya ialah:

a. Hibah dapat menyatukan hati dan menguatkan ikatan cinta antar manusia. Abu Hurairah r.a meriwayatkan bahwa Nabi SAW bersabda: "Saling memberi hadiahlah kalian, niscaya kalian akan saling mencintai".

b. Hibah dapat menghilangkan rasa dendam. Dalam sebuah hadist dari Abu Hurairah yang meriwayatkan bahwa Nabi saw bersabda: "Saling memberi hadiahlah kalian karena hadiah itu menghilangkan kedengkian hati. Dan janganlah sekali-kali seorang tetangga merendahkan pemberian tetangganya meskipun itu hanya separuh kaki seekor kambing". 


\section{METODE PENELITIAN}

Dalam skripsi ini penulis menggunakan pendekatan perundangundangan (statue approach) dan pendekatan kasus (case approach). Pendekatan undang-undang ialah pendekatan yang dilakukan dengan menelaah semua undang-undanng dan regulasi yang bersangkutan dengan isu hukum yang ditelaah. Hasil dari telaah tersebut merupakan suatu argumen untuk memecahkan isu yang diteliti. Sedangkan pendekatan kasus ialah dengan meneliti alasan-alasan hukum yang dipergunakan oleh hakim untuk sampai kepada putusannya, dengan memperhatikan fakta materill. Fakta-fakta tersebut berupa orang, tempat, waktu, dan segala yang menyertainya asalkan tidak terbukti sebaliknya (Marzuki, 2017: 197). Melalui pendekatan ini penulis dapat menelaah dan mengkaji mengenai penerapan hukum islam dan hukum positif dalam putusan No $467 \mathrm{~K} / \mathrm{Ag} 2017$.

Untuk mendapatkan sumber data yang diperlukan dalam penulisan ini, maka sumber data yang penulis gunakan, yaitu (Soekanto, 1986:43):

1. Sumber data primer, yaitu data yang diperoleh penulis dari lapangan berupa berkas putusan perkara pembatalan hibah. Yakni berkas putusan Mahkamah Agung dalam perkara No 467 K/Ag2017 mengenai pembalan hibah harta bersama yang diberikan orang tua terhadap anak.

2. Sumber data sekunder, yaitu data yang memberikan penjelasan mengenai data hukum primer dan implementasinya. Untuk penelitian ini bahan hukum sekunder tersebut dibagi menjadi 4 bagian, yaitu:

a. Bahan hukum primer

Bahan hukum primer adalah bahan hukum yanh diperoleh dan secara langsung mendukung tindakan yang terdapat didalam data primer dan di gunakan dalam penelitian. Bahan hukum primer yang digunakan dalam penelitian ini terdiri dari:

1) Undang-Undang Nomor 1 Tahun 1974 Tentang Perkawinan

2) Instruksi Presiden Republik Indonesia Nomor 1 Tahun 1991 Tentang Kompilasi Hukum Islam

3) Kitab Undang-Undang Hukum Perdata

b. Bahan hukum sekunder

Bahan hukum sekunder adalah bahan-bahan yang erat kaitannya dengan bahan hukum primer dan dapat membantu 
menganalisis dan memahami bahan hukum primer. Bahan hukum sekunder yang digunakan dalam penelitian ini terdiri dari buku-buku, Jurnal Hukum, Skripsi, atau bahan pustakan lain yang berkaitan dengan materi penelitian.

c. Bahan hukum tersier

Bahan hukum tersier adalah bahan-bahan hukum yang memberikan petunjuk atau penjelasan terhadap bahan hukum primer dan bahan hukum sekunder. Bahan hukum tersier yang digunakan penulis dalam penelitian ini ialah:

1) Kamus Besar Bahasa Indonesia

2) Artikel dari Internet

\section{PEMBAHASAN}

Pertimbangan Hukum Hakim Tingkat Pertama Hingga Kasasi Jika dilihat dari amar putusan perkara dari tingkat pertama hingga kasasi terdapat perbedaan pendapat pertimbangan hukum hakim dalam memutus perkara pembatalan hibah harta bersama ini. Yakni terhadap dasar hukum yang digunakan dalam memutus perkara pembatalan tersebut. Dilihat dari amar putusan tingkat pertama yaitu putusan Pengadilan Agama No 0072/Pdt.G/2016/PA.Sby, penulis berpendapat bahwa majelis hakim lebih condong menggunakan Pasal 1678 KU Perdata dalam pertimbangan hukumnya yang menyatakan bahwa "ketika surat hibah tersebut dibuat, Penggugat dan Tergugat I masih berstatus suami istri. dan istri bersedia dicerai dengan syarat menghibahkan harta kepada anak-anaknya sehinggayang dihibahkan adalah harta bersama antara Pengggugat dengan Tergugat I. Menurut Pasal 1678 KUHPerdata pemberian suami kepada istri atau sebaliknya tidak dibenarkan" (Salinan Putusan perkara nomor 0072/Pdt.G/2016/PA.Sby).

Dalam Pasal 1678 KUH Perdata yang menyatakan bahwa: "Penghibahan antara suami istri selama perkawinan mereka masih berlangsung, dilarang. Tetapi ketentuan ini tidak berlaku terhadap hadiah atau pemberian berupa barang bergerak yang berwujud, yang harganya tidak mahal kalau dibandingkan dengan besarnya kekayaan penghibah".

Didalam pasal tersebut menjelaskan mengenai larangan untuk melakukan perjanjian penghibahan antara suami istri yang masih 
terikat dalam perkawinan, sehingga penghibahan antara suami istri merupakan sebuah perbuatan melawan hukum. Suatu perjajian yang dianggap sebagai perbuatan melawan hukum, berdasarkan ketentuan Pasal 1320 KUH Perdata tentang syarat sahnya perjanjian pada poin yang keempat yaitu suatu sebab yang tidak terlarang, maka perjanjian hibah antara suami istri tersebut tidak memenuhi syarat sah perjanjian, sehingga mengakibatkan perjanjian tersebut batal demi hukum. Apabila perjanjian batal demi hukum, artinya dari semula tidak pernah dilahirkan suatu perjanjian, dan dengan demikian tidak pernah ada suatu perikatan (Dewantara, t.t:5).

Dalam Pasal 1678 KUH Perdata diantara suami istri tidak boleh menghibahkan sesuatu yang bernilai tinggi. Ini dikarenakan dapat menimbulkan dampak negatif di kemudian hari. Semisal, seorang perempuan menikah dengan seorang duda dan sudah mempunyai anak. Kemudian si pria/suami tersebut menghibahkan rumahnya kepada istri barunya, hal seperti ini dapat merugikan ahli waris dari suami tersebut. Sehingga penghibahan antara suami istri selama terikat perkawinan, dilarang.

Penulis berpendapat bahwa Pasal 1678 KUH Perdata yang dijadikan pertimbangan hakim Pengadilan Agama tersebut kurang sesuai. Dikarenakan Pasal 1678 KUH Perdata digunakan untuk penghibahan antara suami istri. Sedangkan hibah yang di bahas dalam perkara ini ialah hibah orang tua terhadap anak, dimana pemberi hibah adalah Penggugat (suami) dan penerima hibah adalah Tergugat I (istri) sebagai wakil dari anak-anak yang saat itu belum cakap hukum. Sehingga penggunaan Pasal 1678 KUH Perdata tersebut kurang tepat.

Kemudian dasar pertimbangan hakim Pengadilan Agama yang menyatakan bahwa "karena obyek yang dihibahkan adalah harta bersama Penggugat dan Tergugat I, maka hibah yang dilakukan Penggugat terhadap anak-anaknya adalah tidak berdasarkan hukum, karena salah satu syarat hibah adalah obyek yang dihibahkan harus menjadi hak milik penuh pemberi hibah sendiri dan bukan harta yang masih terkait dengan pihak lain. Hal ini sebagaimana dikehendaki oleh ketentuan Pasal 210 ayat (2) Kompilasi Hukum Islam dan juga Yurisprudensi Mahkamah Agung Nomor 332K/AG/2000" (Salinan Putusan Perkara Nomor 0072/Pdt.G/2016/PA.Sby).

Dalam pertimbangan hakim Pengadilan Agama tersebut jika disesuaikan dengan Pasal 36 ayat (1) Undang-Undang No 1 Tahun 1974 
yang menyatakan bahwa "Mengenai harta bersama, suami atau istri dapat bertindak atas persetujuan kedua belah pihak". Berdasarkan Pasal 36 ayat (1) tersebut, dalam harta bersama masing-masing suami dan istri memiliki hak dan kewajiban yang sama atas harta bersama tersebut. Hak ini berlaku juga bagi istri walaupun suami yang mencari nafkah sedangkan istri hanya di rumah mengurus rumah tangga.

Namun demikian, walaupun memiliki kesamaan hak atas harta bersama tersebut, baik suami maupun istri tidak bisa menyalahgunakan harta tersebut. Artinya segala sesuatu yang berhubungan dengan penggunaan harta bersama tersebut harus berdasarkan kesepakatan dan persetujuan dari kedua belah pihak(suami dan istri). Sehingga dapat disimpulkan bahwa hibah yang di berikan Penggugat terhadap anak-anaknya adalah berdasarkan hukum. Karena pemberian hibah atas harta bersama tersebut telah di setujui oleh kedua belah pihak (suami-istri) dengan dinyatakan di hadapan majelis hakim perkara cerai kala itu.

Dari pernyataan Majelis Hakim Pengadilan Agama yang berpendapat bahwa "hibah yang dinyatakan Penggugat adalah tidak berdasarkan hukum, oleh karena itu gugatan Penggugat tentang pembatalan hibah tidak mempunyai dasar hukum". Apabila pertimbangan hakim yang menyatakan hibah tersebut tidak berdasarkan hukum, maka seharusnya surat pernyataan hibah yang dilakukan Penggugat untuk anak-anknya tersebut dapat dibatalkan dan gugatan penggugat dapat dikabulkan.

Berbeda dengan pertimbangan Hakim tingkat pertama, dalam pertimbangan hakim tingkat banding yaitu Pengadilan Tinggi Agama Surabaya menyatakan bahwa "menurut majelis tingkat banding, kesepakatan yang dibuat antara Pembanding dengan Terbanding I dalam menghibahkan dan mewasiatkan harta bersama sebagaimana tercantum dalam obyek sengketa 1,2,3,4,5,6 dan 7 tersebut telah mendapat persetujuan Terbanding I dan telah memenuhi syarat subyektif dan obyektif sebagaimana yang dimaksud oleh Pasal 1320 KUH Perdata, serta dalam proses persidangan tidak terbukti adanya unsur-unur sebagaimana yang dimaksud oleh Pasal 1321 KUH Perdata, yaitu unsur kekhilafan, paksaan, dan penipuan. Maka menurut majelis tingkat banding perbuatan hukum (hibah dan wasiat) atas harta bersama tersebut dapat dibenarkan dan dinyatakan sah menurut 
hukum" (Salinan Putusan Perkara Nomor 32/Pdt.G/2017/PTA.Sby). Sehingga dalam hal ini Penulis lebih condong setuju dengan pertimbangan hukum Hakim pada tingkat banding yaitu Pengadilan Tinggi Agama Surabaya yang membernarkan dan menyatakan sah pernyataan hibah atas harta bersama yang dilakukan oleh Penggugat terhadap anak-anaknya.

Kemudian, jika dilihat dari pertimbangan hakim Pengadilan Tinggi Agama Surabaya dan Mahkamah Agung yang dalam putusannya lebih condong pada Pasal 1338 KUH Perdata saja. Dimana dalam Pasal 1338 yang menyatakan bahwa "suatu perjanjian yang dibuat secara sah berlaku sebagai undang-undang bagi mereka yang membuatnya. Perjanjian itu tidak dapat ditarik kembali selain dengan sepakat kedua belah pihak, atau karena alasan-alasan oleh undangundang dinyatakan cukup untuk itu. Perjanjian harus dilaksanakan dengan I'tikad baik".

Berdasarkan Pasal 1338 KUH Perdata tersebut, suatu persetujuan atau perjanjian yang telah dibuat oleh kedua belah pihak tidak boleh dibatalkan oleh salah satu pihak saja, dan hanya dapat dibatalkan oleh salah satu pihak dengan persetujuan pihak lainnya. Dalam perkara ini Penggugat yang meminta pembatalan hibah atas harta bersama tersebut tidak disetujui oleh Tergugat I selaku mantan istri serta pemilik setengah dari harta bersama tersebut. Bahwa satu alasan Tergugat I tidak menyetujui pembatalan hibah yang diajukan Penggugat ialah karena objek hibah saat ini telah berubah dari bentuk sebelumnya, yaitu (Salinan Putusan Perkara nomor 0072/Pdt.G/2016/PA.Sby):

a. Tanah dan rumah yang terletak di Jalan Manyar Sabrangan III/31 Surabaya telah bertambah luasnya dari hasil beli dan rumahnya dibangun diperlebar.

b. Tanah dan rumah yang terletak di Jalan Manyar Sabrangan III/33 Surabaya dikontrakkan pihak lain dan hasilnya setelah dikurangi biaya pemeliharaan dibagi kepada Para Tergugat.

c. Tergugat III telah membangun rumah diatas tanah hibah pada tahun 1985 dan ditempati sampai sekarang.

d. Tergugat IV telah membangun rumah diatas tanah hibah pada tahun 2010 dan ditempati sampai sekarang. 
e. Tanah yang di Semolo Waru oleh Tergugat $\mathrm{V}$ telah dibangun rumah pada tahun 1999 dan ditempati Tergugat V sampai sekarang.

f. Tergugat IV membangun rumah diatas tanah hibah tahun 2008 dan ditempati sampai sekarang.

g. Sisa tanah hibah dibangun rumah pada tahun 1993 disewakan ke pihak lain dan hasilnya dibagi kepada Para Tergugat.

h. Tergugat II membangun rumah diatas tanah hibah tahun 2014 dan ditempati sampai sekarang

Dapat disimpulkan bahwa objek hibah yang kala itu dihibahkan kepada anak-anak saat ini telah berubah semua. Dan pernyataan hibah itu sudah berjalan 34 tahun. Yaitu pada tahun 1981 hingga 2016 ketika perkara hibah ini digugat di Pengadilan Agama Surabaya oleh Penggugat. Sesuai dengan Pasal 1967 KUH Perdata yang mengatakan bahwa "semua tuntutan hukum, baik yang bersifat kebendaan maupun yang bersifat perorangan, hapus karena lewat waktu dengan lewatnya waktu tiga puluh tahun, sedangkan orang yang menunjuk adanya lewat waktu itu, tidak usah menunjukkan suatu alas hak, dan terhadapnya tak dapat diajukan suatu tangkisan yang didasarkan pada itikad buruk" sehingga gugatan Penggugat dalam melakukan tuntutan hukum terkait pembatalan hibah atas harta bersama tersebut sudah melewati tenggat waktu karena sudang berlangsung hingga 34 tahun. Disamping itu, ditinjau dari kedudukan berkuasa (bezit), jelas hibah atas tanah dan bangunan tersebut tidak dapat ditarik kembali.

Kedudukan berkuasa ialah kedudukan seseorang yang menguasai suatu kebendaan, baik dengan diir sendiri, maupun dengan perantara porang lain, dan yang mempertahankan atau menikmatinya selaku orang yang memiliki kebendaan itu. (KUH Perdata Pasal 529). Dalam Pasal 545 dijelaskan bahwa berakhirnya kedudukan berkuasa baginya atas sebidang tanah, perkarangan atau bangunan ialah karena: 1) apabila orang lain, setelah dengan tak mempedulikan kehendak si yang berkedudukan, menarik kebendaan-kebendaan itu dalam kekuasaannya, dan kemudian selama setahun menikmatinya tanpa suatu gangguan apapun juga, 2) apabila sebidang pekarangan karena suatu peristiwa luar biasa telah tenggelam kebanjiran.

Setelah penjabaran mengenai pertimbangan hukum hakim di atas, dapat ditarik kesimpulan bahwa benar hibah yang telah diberikan tidak 
dapat ditarik kembali. Namun karena perkara ini telah diambil alih oleh Pengadilan untuk diselesaikan secara hukum yang berlaku, sehingga Pengadilan mempunyai hak penuh atas memutus suatu perkara yang terjadi. Dalam hal ini penulis berpendapat jika Pengadilan dapat meninjau kembali dan melihat peraturan-peraturan terkait pembatalan hibah harta bersama ini secara lebih luas. Sehingga putusan terhadap perkara ini dapat berubah. Semisal dengan menyatakan bahwa pembatalan hibah atas harta bersama tersebut dapat dikabulkan sebagian.

Mengingat Penggugat juga mempunyai hak atas harta bersama tersebut, dan disamping itu Penggugat juga merupakan orang tua penerima hibah, sehingga hibah dapat dibatalkan sebagian sesuai dengan ketentuan Kompilasi Hukum Islam Pasal 212.

\section{E. KESIMPULAN}

Berdasarkan uraian di atas, maka penulis menyimpulkan bahwa putusuan Hakim terkait gugatan pembatalan hibah dalam perkara Nomor 467/K.Ag/2017 yang menyatakan tidak dapat dibatalkan atau tidak dapat ditarik kembali kecuali persetujuan kedua belah pihak (suami-istri) adalah benar dalam hal ini Tergugat I tidak bersedia hibahnya dibatalkan. Alasan lain terkait tidak dikabulkannya gugatan Penggugat ialah karena gugatan terhadap objek hibah tersebut telah lewat waktu, yakni 34 tahun yang mana telah melampaui masa daluarsa suatu gugatan diajukan dan selama 34 tahun itu tidak pernah di utak-atik atau dipermasalahkan oleh Penggugat. Tetapi menurut Penulis pertimbangan hukum hakim terdapat celah, yaitu dilihat dari ketentuan dalam Kompilasi Hukum Islam Pasal 212 yang menyatakan bahwa hibah tidak dapat ditarik kembali kecuali hibah orang tua terhadap anak. Sehingga gugatan terkait pembatalan hibah tersebut dapat dipertimbangkan dikabulkan sebagian mengigat Penggugat adalah orangtua dari anak-anaknya.

\section{DAFTAR PUSTAKA}

Ajib, Muhammad. (2019). Fiqih Hibah dan Waris. Jakarta: Rumah Fiqih Publishing.

Al Bukhari Al-Ju'fi, Muhammad bin Ismail Abu Abdullah Shahih Bukhari (Al Jami Al-Musnad as-Sahih Al-Mukhtasar min Umur 
Raulullah SAW wa Sunanihi wa Ayyamihi), Dar Touq AlNajah, Juz 9.

As-Syaibani, Abu Abdullah Ahmad bin Muhammad bin Hambal bin Hilal bin Asad, Musnad Imam Ahmad Bin Hambal.

Az-Zuhaili, Wahbah. (2011). Fiqih Islam Wa Adillatuhu, Vol.5. Jakarta:

Gema Insani.

Bazzar, Abu Bakar Ahmad bin Amru bin Abdul Khaliq bin Khollad bin

Ubaidillah Al-Ataki, Musnad al-Bazar (al-Bahr al-Zakhkhar), Madinah: Perpustakaan Ilmu Pengetahuan dan Pemerintahan, Juz 18.

Dewantara, J. A., Sarjana, I. M., \& Darmadha, I. N. (t.t). Akibat Hukum Pembatalan Hibah Istri Terhadap Suami Setelah Adanya Perceraian (Analisis Kasus: Putusan Mahkamah Agung Nomor 1893 K/PDT/2015). Kertha Semaya: Journal Ilmu Hukum, 7(5), 1-13.

Hibah Orang Tua kepada Anak-anaknya dan Kaitannya dengan Waris https://m.hukumonline.com/klinik/detail/ulasan/cl5203/hibahh adiah--warisan/ diakses tanggal 28 Mei 2020 Pada Jam 19.46.

Instruksi Presiden Republik Indonesia No 1 Tahun 1991 tentang Kompilasi Hukum Islam.

Keberlakuan Kitab Undang-Undang Hukum Perdata https://m.hukumonline.com/klinik/detail/ulasan/lt4fd28218473 36/jerat/ diakses pada tanggal 15 Juli 2020 pada jam 22.38.

Manan, Abdul. (2008). Aneka Masalah Hukum Perdata Islam di Indonesia. Jakarta: Kencana.

Mardani. (2014). Hukum Kewarisan Islam di Indonesia. Jakarta: Rajagrafindo Persada.

Marzuki, Peter Mahmud. (2017). Penelitian Hukum. Jakarta: Kencana.

Oping, M. S. R. (2017). Pembatalan Hibah Menurut Pasal 1688 Kitab Undang-Undang Hukum Perdata. Lex Privatum, 5(7).

Rofiq, Ahmad. (2013). Hukum Perdata Islam di Indonesia. Jakarta: Raja Grafindo Persada.

Sabiq, Sayyid. (2009). Fiqih Sunnah. Jakarta: Pena Pundi Aksara.

Soekanto, Soerjono. (1986). Pengantar Penelitian Hukum. Jakarta: UI Press.

Suparman, Eman. (2007). Hukum Waris Indonesia dalam Perspektif Islam, Adat, dan BW. Bandung: Reafika Aditama. 
Tjitrosudibio, R. Subekti. (2014). Kitab Undang-Undang Hukum Perdata. Jakarta: Balai Pustaka.

Tjitrosudibio, R. Subekti. (1999). Kitab Undang-Undang Hukum Perdata. Jakarta: Pradya Paramita.

Zuhrotunnisa, Fifin. (2017). Pembatalan Hibah, Skripsi Fakultas Syariah dan Hukum, Universitas Islam Negeri Syarif Hidayatullah Jakarta. 